\title{
O primado da afetividade na comunicação Uma crítica teológico-pastoral ao modelo tradicional de mediação de conflitos
}

Orientador: Prof. Dr. Abimar Oliveira de Moraes

abimar@puc-rio.br

Pesquisadora: Denise Pires dos Santos

denise.pires@gmail.com

Projeto de Pesquisa: Questões atuais de Teologia Pastoral

Fonte: $\mathrm{CNPq}$

Nessa pesquisa foi feita uma investigação qualitativa dos procedimentos do modelo de Mediação de Conflitos escolhido e adotado neste momento pelo TJERJ: o modelo tradicional de mediação judicial denominado Modelo Pragmático que privilegia o acordo (mais rápido e independente do processo judicial). Além de considerar os resultados alcançados, relevou igualmente a formação de mediadores e mediadoras que buscam adequar-se ao modelo escolhido frente às necessidades atuais e objetivos almejados pelo Poder Judiciário. Estudando qualitativamente os procedimentos desse modelo tradicional, verificou-se se tais procedimentos respondem à premente necessidade de novas ferramentas para minimizar a grande demanda de conflitos interpessoais e comunitários que vêm ganhando proporções assustadoras na nossa sociedade. 